\title{
WALTER BAPTIST MORS
}

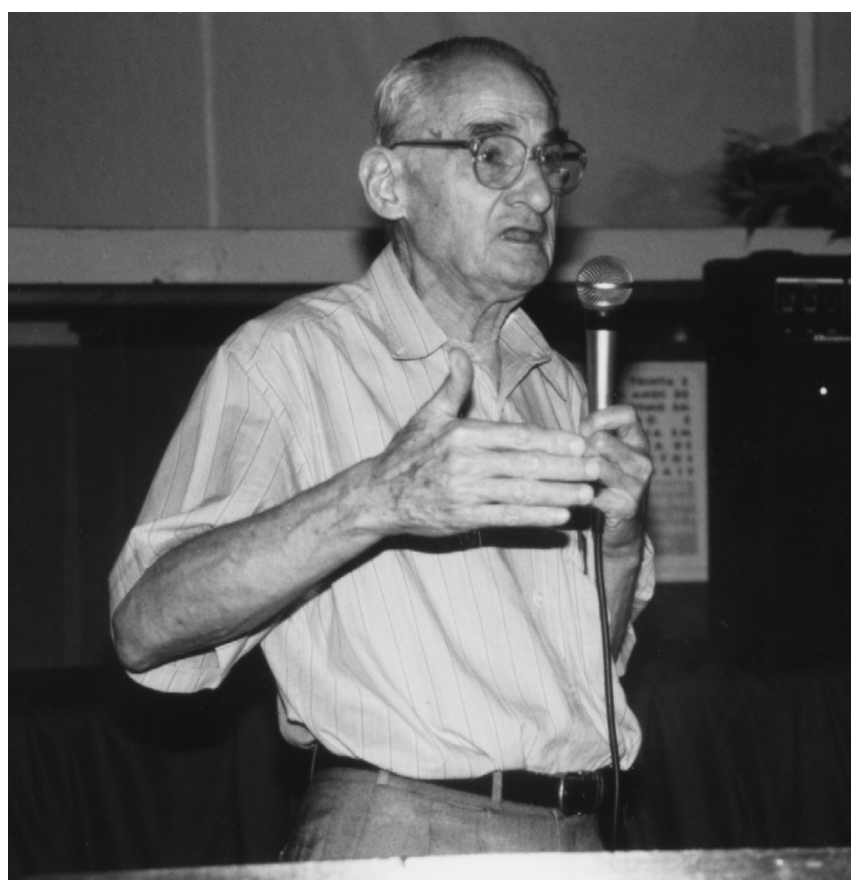

Nascido em São Paulo no ano de 1920, Walter Baptist Mors bacharelou-se em Química pela Faculdade de Filosofia, Ciências e Letras da Universidade de São Paulo e obteve a livre-docência pela Universidade do Brasil, hoje Universidade Federal do Rio de Janeiro. Pesquisador 1-A do CNPq, foi eleito Membro Titular da Academia Brasileira de Ciências em 1959, sendo secretário-geral da ABC durante três mandatos. Walter Mors atuou no Instituto Agronômico do Norte do Ministério da Agricultura, em Belém, Pará. Foi lá que adquiriu o gosto pela Botânica Econômica que cultivou durante toda a vida. Mais tarde transferiu-se para o Instituto de Química Agrícola, no Rio de Janeiro, onde consolidou sua afeição pela química dos produtos naturais e seu interesse pelas relações entre química e sistemática botânica. Como bolsista da Fundação Rockefeller, trabalhou então na Wayne State University, em Detroit, com o Prof. Carl Djerassi, uma das maiores estrelas da Química de Produtos Naturais de todos os tempos e o impulsionador desta área, nos anos 60, no Rio de Janeiro.

Em colaboração com muitos colegas e alunos produziu uma longa série de trabalhos sobre produtos naturais. A última pesquisa foi relativa a plantas que o uso popular consagrou como antiofídicas. Suas pesquisas demonstraram a veracidade desta reputação, que levou ao isolamento de várias substâncias responsáveis pela proteção que estas plantas conferem contra a ação dos venenos de cobras. Das dezenas de artigos científicos que publicou, se destaca a identificação do epoxigeranilgeraniol como a substância ativa do óleo obtido dos frutos da sucupira-branca (Ptedoron pubescens), que impede a penetração das cercárias do Schistosoma mansoni na pele do hospedeiro, publicado na prestigiosa revista Science, e a identificação do princípio ativo da planta anti-diabética pedra-ume-caá.
Foi co-autor, juntamente com seus grandes amigos e colaboradores Carlos Toledo Rizzini e o também Acadêmico Nuno Álvares Pereira, de uma das bíblias da área, "Medicinal Plants of Brazil". Com Rizzini publicou "Botânica Econômica Brasileira", uma das obras mais importantes da botânica brasileira, antes publicada como "Useful Brazilian Plants."

Aposentado desde 1991, Walter Mors continuou colaborando com o Núcleo de Pesquisas de Produtos Naturais da UFRJ, do qual era co-fundador e foi diretor por duas vezes. Tornou-se presidente de honra da Associação Brasileira de Química em 1993, foi presidente da Federacion Latinoamericana de Asociaciones Químicas (FLAQ) e membro eleito da Linnean Society of London. Foi membro do Conselho da Finep. Recebeu, em 2001, a Medalha Simão Mathias da Sociedade Brasileira de Química (SBQ) e em 1994 a Grã-Cruz da Ordem Nacional do Mérito Científico do Presidente da República do Brasil.

Seu discípulo, Prof. Lauro Barata, em texto enviado a vários membros da comunidade científica, lembra-se do Prof. Mors sempre tão ocupado mas dedicado a seus orientandos e acreditando, acima de tudo, na sua ciência, no potencial químico dos produtos naturais. Coletava plantas, transformava-as em extratos e testava-as. "Preparava o futuro, escrevia para o mundo, publicava indistintamente em francês, inglês ou alemão, línguas que também falava, e ainda conseguia um tempinho para gente como nós, os recém-chegados da Bahia, Pará e alhures, ao mundo da Ciência."

Segundo o Prof. Barata, Walter Mors inventou o conceito de redes, hoje tão em moda quando, em torno de 1970, coordenou um grupo pluridisciplinar que chamou de "Projeto Integrado", juntando químicos, botânicos e farmacologistas num time que pudesse transformar a riqueza florística brasileira em medicamentos, cosméticos e em bioinseticidas.

O respeito que o Prof. Lauro Barata e os outros membros do grupo tinham por Walter Mors, segundo ele, beirava a devoção, porque ele era um verdadeiro educador. "Com ele podíamos falar não só de Química, mas de Mozart, Bach ou de Nobéis, ou dos artigos mais recentes da Science e Nature, suas revistas de cabeceira. Ele agora se foi, com tantas coisas na sua cabeça privilegiada, e aqui ficamos nós, responsáveis pelo seu legado, redutos dos seus anseios de transformar as matérias-primas naturais desse Brasil em produtos para a sociedade."

O Professor Mors faleceu no Rio de Janeiro no dia 6 de outubro. Seu pioneirismo na química de produtos naturais no Brasil o coloca para sempre na história da ciência brasileira.

(Adaptado do boletim da Academia Brasileira de Ciências) 